\title{
Eucalyptus Psyllid, Blastopsylla occidentalis Taylor and Red Gum Lerp Psyllid, Glycaspis brimblecombei Moore (Insecta: Hemiptera: Psyllidae) ${ }^{1}$
}

Susan E. Halbert, Raymond Gill, and ames N. Nisson²

\section{Introduction}

Two psyllids that feed on Eucalyptus were found for the first time in Florida in the spring of 2001 in tourist parks in the Orlando area: Glycaspis brimblecombei Moore, the red gum lerp psyllid, and Blastopsylla occidentalis Taylor, the eucalyptus psyllid. Both species originate in Australia and already are well established in California, which is the most likely immediate source of the Florida populations.

\section{Distribution}

Both Blastopsylla occidentalis and Glycaspis brimblecombei are native to Australia and occur in California. B. occidentalis has been found in Mexico and New Zealand (Taylor 1985, Hodkinson 1991, Gill 1998, Brennan and Gill 1999). Glycaspis brimblecombei has a wide distribution in East Central Australia and frequently occurs together with other members of the genus (Moore 1975).

\section{Description}

G. brimblecombei and B. occidentalis are the only psyllids known to feed on Eucalyptus in Florida. Infestations of Glycaspis brimblecombei are most easily recognized by the conical white coverings (lerps) secreted by the nymphs. The psyllid nymphs are reddish bronze with darker wing pads that have bright white spots. Adults are yellow to green in color and are winged and highly mobile. The anterior part of the head of the adults has a pair of curious long projections called genae. Blastopsylla occidentalis does not make lerps, but nymphs of these insects do secrete a waxy substance. Adults are smaller than those of G. brimblecombei, and the genae are much shorter.

\section{Life History}

Both psyllids are obscure species in Australia, and little is known about their life histories. Clark and Dallwitz (1974) published seasonal abundance

1. This document is EENY-306 (originally published as DPI Entomology Circular 407), one of a series of Featured Creatures from the Entomology and Nematology Department, Florida Cooperative Extension Service, Institute of Food and Agricultural Sciences, University of Florida. Published: October 2003. This document is also available on Featured Creatures Website at http://creatures.ifas.ufl.edu. Please visit the EDIS Website at http://edis.ifas.ufl.edu. Additional information on these organisms, including many color photographs, is available at the Entomology and Nematology Department website at http://entnemdept.ifas.ufl.edu/.

2. Susan E. Halbert, Florida Department of Agriculture and Consumer Services, Division of Plant Industry; Raymond Gill, California Department of Agriculture; and James N. Nisson, Orange County (California) Agriculture Commissioner's Office.

The Institute of Food and Agricultural Sciences (IFAS) is an Equal Employment Opportunity - Affirmative Action Employer authorized to provide research, educational information and other services only to individuals and institutions that function without regard to race, creed, color, religion, age, disability, sex, sexual orientation, marital status, national origin, political opinions or affiliations. For information on obtaining other extension publications, contact your county Cooperative Extension Service office. Florida Cooperative Extension Service / Institute of Food and Agricultural Sciences / University of Florida / Larry R. Arrington, Interim Dean 


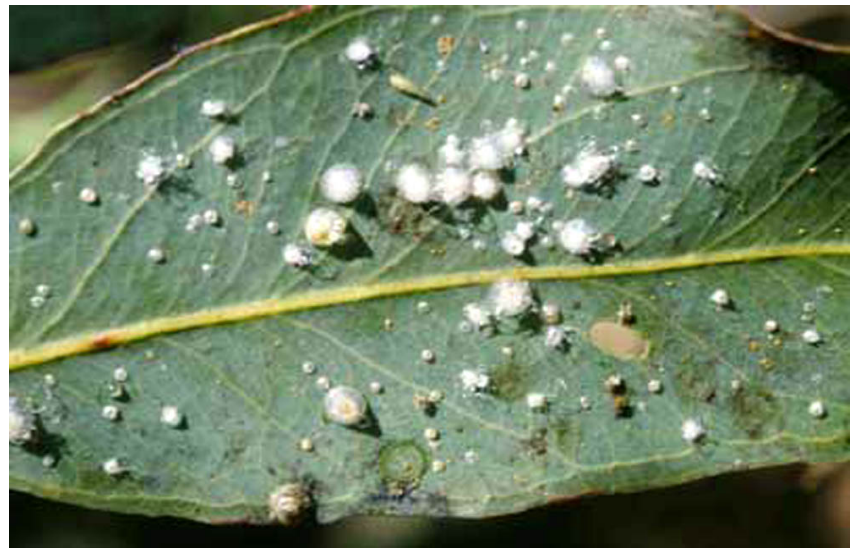

Figure 1. Nymphs and adult of G. brimblecombei Moore, a psyllid pest of Eucalyptus spp. Credits: Photograph by: Jeffrey Lotz, DPI, FDACS

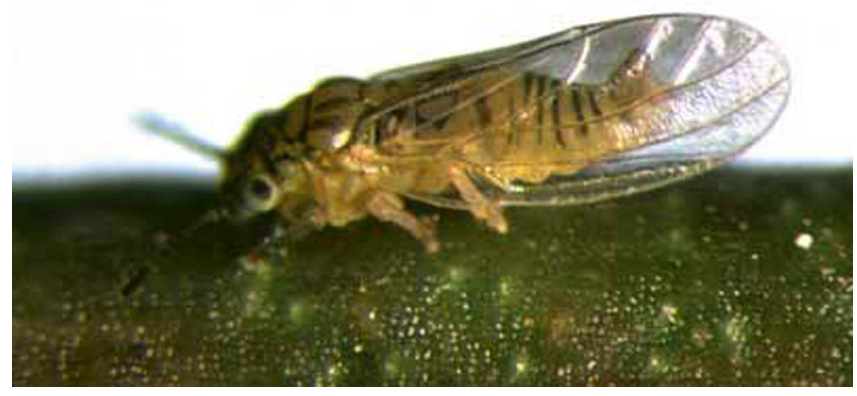

Figure 2. Adult Blastopsylla occidentalis Taylor, a psyllid pest of Eucalyptus spp. Credits: Photograph by: Raymond Gill, California Department of Agriculture

information about Glycaspis spp. Information on several Glycaspis species was pooled because they were unable to distinguish the nymphs. The main factors regulating the population appeared to be the suitability of host material. The trees have a two-year fruiting cycle, and the stage of that cycle greatly influenced the numbers of Glycaspis.

Other factors affecting abundance included fruit production (unfavorable), damage by leaf beetles (unfavorable), soil moisture (moist conditions favorable), and drought in the previous season (favorable). The psyllids were most abundant in the fall and winter months, and higher temperatures during that time were favorable to Glycaspis abundance. It was noted that Eucalyptus trees in an urban area had higher populations than similar trees in a natural setting. Several reasons were cited, including the fact that the urban trees were irrigated during the hot part of the year. Secondly, the urban trees had sustained heavy damage due to leaf-feeding beetles and consequently had produced little fruit compared with their counterparts in the natural setting.

Glycaspis brimblecombei is more damaging than other eucalyptus psyllids introduced into North America because it can defoliate the trees, and it has a relatively broad host range among Eucalyptus spp. (Brennan and Gill 1999).

Virtually nothing is known about the life history of B. occidentalis. It is reported to damage Eucalyptus in New Zealand (Satchell 1999).

\section{Hosts}

Brennan and Gill (1999) list the following Eucalyptus species as hosts of G. brimblecombei from literature:

E. blakelyi Maiden

E. brassiana Blake

E. bridgesiana Baker

E. camaldulensis Dehnh.

E. camphora Baker

E. dealbata Cunn. Ex Schauer

E. mannifera ssp. Maculosa Baker

E. nitens Deane \& Maiden

E. teriticornis Smith.

In California, G. brimblecombei also has been found on: E. diversicolor F. Muell

E. globulus Labill

E. sideroxylon Cunn (Brennan and Gill 1999).

Taylor (1985) lists the following hosts for $B$. occidentalis in the original description: E. microtheca F. Muell.

E. rudis Endl. 
E.gomphocephala DC.

E. camauldulensis Dehnh.

E. ? platypus Hook.

E. oleosa F. Muell.

E. forrestiana Diels.

E. ? microneura Maiden \& Blakely

E. nicholii Maiden \& Blakely

E. spathulata Hook.

The specimens from $E$. spathulata came from California. In South America, B. occidentalis is reported from E. urophylla S.T. Blake and hybrids of E. urophylla and E. grandis A.W. Hill ex Maiden.

\section{Survey and Detection}

The easiest way to survey for $G$. brimblecombei is to examine both old and new leaves for lerps. Frequently, infested trees are obviously dripping with honeydew and old lerps. Survey for B. occidentalis by checking new growth for fuzzy flocculent secretions.

\section{Key to Psyllids Found on Eucalyptus in North America}

The following literature, was used in constructing the key: Burckhardt et al. (1999), Gill (2000), Morgan (1984), Taylor (1985, 1987, 1990), and Tuthill and Taylor (1955).

1. Metacoxae of adults without meracanthi (large spines) ..... 2

1'. Metacoxae of adults with meracanthi (Ctenarytaina) $(\mathrm{CA}) \ldots .5$

2. Genal cones long, $0.8 \mathrm{x}$ length of vertex or longer; forewings apically angulate, lerps present, (CA, FL) ..... Glycaspis brimblecombei

2'. Genal cones shorter, less than $0.7 \mathrm{x}$ length of vertex, forewings rounded apically ..... 3

3. Proximal (basal) segment of metatarsus with two black spines ..... 4
3'. Proximal (basal) segment of metatarsus with one black spine (CA, FL) . . . . Blastopsylla occidentalis

4. Ratio of metatibia length to metafemur length 1.5 or greater; lerps present (CA) . . . . .

Eucalyptolyma maideni

4'. Ratio of metatibia length to metafemur length 1.0 or less, male parameres with a dorsal row of peg-like, black spines along margin (CA) . . . . Cryptoneossa triangula

5. Male proctiger with a row of simple setae at apex of basal segment, stout spine lacking, dull grey, brown (CA) .... . Ct. longicauda

5b. Male proctiger with a stout spine or peg at ventral apices of basal segment .... 6

6. Male proctiger with apical segment elongate, $2 / 3$ or greater the length of basal segment; parameres elongate and broad, each as broad as proctiger in lateral view at widest points; head and thorax dorsally yellowish with brown spots (CA) .... Ct. spatulata

6'. Male proctiger with apical segment 0.5 times or less the length of the basal segment; parameres $2 / 3$ or less the width of the proctiger at widest points; head and thorax dorsally dark brown to black (CA) ..... Ct. eucalypti

\section{Selected References}

Brennan EB, Gill RJ. 1999. First record of Glycaspis brimblecombei (Moore) (Homoptera: Psyllidae) in North America: Initial observations and predator associations of a potentially serious new pest of Eucalyptus in California. Pan-Pacific Entomologist 75: 55-57.

Burckhardt, D, Santana DLQ, Terra AL, de Andrade FM, Penteado SRC, Iede ET, Morey CS. 1999. Psyllid pests (Hemiptera, Psylloidea) in South American eucalypt plantations. Mitteilungen der Schweizerischen Entomolgischen Gesellschaft. Bulletin de la Société Entomologique Suisse 72: 1-10.

Clark LR, Dallwitz MJ. 1974. On the relative abundance of some Australian Psyllidae that coexist 
on Eucalyptus blakelyi. Australian Journal of Zoology

22: $387-415$.

Gill R. 2000. Spotted gum lerp psyllid.

California Plant Pest and Disease Report 19: 26-27.

Gill R. 1998. Redgum lerp psyllid. California

Plant Pest and Disease Report 17: 7-8.

Hodkinson I.D. 1991. First record of the Australian psyllid Blastopsylla occidentalis Taylor (Homoptera; Psylloidea) on Eucalyptus (Myrtaceae) in Mexico. Pan-Pacific Entomologist 67: 72.

Moore KM. 1975. The Glycaspis spp. (Homoptera: Psyllidae) associated with Eucalyptus camaldulensis. Proceedings of the Linnean Society of New South Wales 99: 121-128.

Morgan FD. 1984. Psylloidea of South Australia. D.J. Woolman, Government Printer, South Australia. $136 \mathrm{p}$.

Satchell D. 1999. Eucalypt psyllids. Forest Health News 88: 1.

Taylor KL. 1990. The tribe Ctenarytainini (Hemiptera: Psylloidea): A key to known Australian genera, with new species and two new genera. Invertebrate Taxonomy 4: 95-121.

Taylor KL. 1987. Ctenarytaina longicauda sp. n. (Homoptera: Psylloidea) from Lophostemon confertus (R. Brown) in Australia and California. Journal of the Australian Entomological Society 26: 229-233.

Taylor KL. 1985. Australian psyllids: A new genus of Ctenarytainini (Homoptera: Psylloidea) on Eucalyptus, with nine new species. Journal of the Australian Entomological Society 24: 17-30.

Tuthill LD, Taylor KL. 1955. Australian genera of the family Psyllidae (Hemiptera: Homoptera). Australian Journal of Zoology 3: 227-257. 